NASA/TM-2010-216920

\title{
Application of the NEXT Ion Thruster Lifetime Assessment to Thruster Throttling
}

Jonathan L. Van Noord

Glenn Research Center, Cleveland, Ohio

Daniel A. Herman

ASRC Aerospace Corporation, Cleveland, Ohio 


\section{NASA STI Program . . . in Profile}

Since its founding, NASA has been dedicated to the advancement of aeronautics and space science. The NASA Scientific and Technical Information (STI) program plays a key part in helping NASA maintain this important role.

The NASA STI Program operates under the auspices of the Agency Chief Information Officer. It collects, organizes, provides for archiving, and disseminates NASA's STI. The NASA STI program provides access to the NASA Aeronautics and Space Database and its public interface, the NASA Technical Reports Server, thus providing one of the largest collections of aeronautical and space science STI in the world. Results are published in both non-NASA channels and by NASA in the NASA STI Report Series, which includes the following report types:

- TECHNICAL PUBLICATION. Reports of completed research or a major significant phase of research that present the results of NASA programs and include extensive data or theoretical analysis. Includes compilations of significant scientific and technical data and information deemed to be of continuing reference value. NASA counterpart of peer-reviewed formal professional papers but has less stringent limitations on manuscript length and extent of graphic presentations.

- TECHNICAL MEMORANDUM. Scientific and technical findings that are preliminary or of specialized interest, e.g., quick release reports, working papers, and bibliographies that contain minimal annotation. Does not contain extensive analysis.

- CONTRACTOR REPORT. Scientific and technical findings by NASA-sponsored contractors and grantees.
- CONFERENCE PUBLICATION. Collected papers from scientific and technical conferences, symposia, seminars, or other meetings sponsored or cosponsored by NASA.

- SPECIAL PUBLICATION. Scientific, technical, or historical information from NASA programs, projects, and missions, often concerned with subjects having substantial public interest.

- TECHNICAL TRANSLATION. Englishlanguage translations of foreign scientific and technical material pertinent to NASA's mission.

Specialized services also include creating custom thesauri, building customized databases, organizing and publishing research results.

For more information about the NASA STI program, see the following:

- Access the NASA STI program home page at http://www.sti.nasa.gov

- E-mail your question via the Internet to help@ sti.nasa.gov

- Fax your question to the NASA STI Help Desk at $443-757-5803$

- Telephone the NASA STI Help Desk at 443-757-5802

- Write to: NASA Center for AeroSpace Information (CASI) 7115 Standard Drive Hanover, MD 21076-1320 
NASA/TM-2010-216920

AIAA-2008-4526

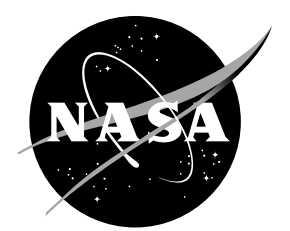

\section{Application of the NEXT Ion Thruster Lifetime Assessment to Thruster Throttling}

Jonathan L. Van Noord

Glenn Research Center, Cleveland, Ohio

Daniel A. Herman

ASRC Aerospace Corporation, Cleveland, Ohio

Prepared for the

44th Joint Propulsion Conference and Exhibit

cosponsored by the AIAA, ASME, SAE, and ASEE

Hartford, Connecticut, July 21-23, 2008

National Aeronautics and

Space Administration

Glenn Research Center

Cleveland, Ohio 44135 
Level of Review: This material has been technically reviewed by technical management.

Available from

NASA Center for Aerospace Information

7115 Standard Drive

Hanover, MD 21076-1320
National Technical Information Service 5301 Shawnee Road Alexandria, VA 22312

Available electronically at http://gltrs.grc.nasa.gov 


\title{
Application of the NEXT Ion Thruster Lifetime Assessment to Thruster Throttling
}

\author{
Jonathan L. Van Noord \\ National Aeronautics and Space Administration \\ Glenn Research Center \\ Cleveland, Ohio 44135 \\ Daniel A. Herman \\ ASRC Aerospace Corporation \\ Cleveland, Ohio 44135
}

\begin{abstract}
Ion thrusters are low thrust, high specific impulse devices with typical operational lifetimes of 10,000 to $30,000 \mathrm{hr}$ over a range of throttling conditions. The NEXT ion thruster is the latest generation of ion thrusters under development. The NEXT ion thruster currently has a qualification level propellant throughput requirement of $450 \mathrm{~kg}$ of xenon, which corresponds to roughly $22,000 \mathrm{hr}$ of operation at the highest input power throttling point. This paper will provide a brief review the previous life assessment predictions for various throttling conditions. A further assessment will be presented examining the anticipated accelerator grid hole wall erosion and related electron backstreaming limit. The continued assessment of the NEXT ion thruster indicates that the first failure mode across the throttling range is expected to be in excess of $36,000 \mathrm{hr}$ of operation from charge exchange induced groove erosion. It is at this duration that the groove is predicted to penetrate the accelerator grid possibly resulting in structural failure. Based on these lifetime and mission assessments, a throttling approach is presented for the Long Duration Test to demonstrate NEXT thruster lifetime and validate modeling.
\end{abstract}

\section{Nomenclature}

$\begin{array}{ll}d_{s} & \text { screen grid hole diameter } \\ \text { ELT } & \text { Extended Life Test } \\ \text { EM } & \text { Engineering Model } \\ f_{p} & \text { fraction of maximum perveance } \\ I_{b} & \text { beam current } \\ j_{b} & \text { beam current density at the beamlet sheath } \\ l_{e} & \text { effective grid gap } \\ l_{g} & \text { grid gap } \\ \text { LDT } & \text { Long Duration Test } \\ \text { NEXT } & \text { NASA's Evolutionary Xenon Thruster } \\ \text { NSTAR } & \text { NASA Solar Electric Propulsion Technology Application Readiness } \\ P & \text { perveance } \\ \text { PFA } & \text { probabilistic failure analysis } \\ \text { PMS } & \text { propellant management system } \\ \text { PPU } & \text { power processing unit } \\ t_{a} & \text { accelerator grid thickness } \\ t_{s} & \text { screen grid thickness } \\ \text { TRL } & \text { technology readiness level }\end{array}$


$V_{b} \quad$ beam power supply voltage

$V_{T} \quad$ total accelerating voltage

\section{Introduction}

NASA's Evolutionary Xenon Thruster (NEXT) project encompasses the development of a high performance, nominal 7-kW, Electric Propulsion Thruster; a light weight, high efficiency power processing unit (PPU); a highly flexible advanced Propellant Management System (PMS); and a lightweight, low-cost gimbal (Refs. 1 and 2). The goal of the NEXT project is to develop the next generation ion propulsion technology to NASA Technology Readiness Level (TRL) 6 (Ref. 3). The NEXT project has built on knowledge gained from the current state-of-the-art NASA Solar Electric Propulsion Technology Application Readiness (NSTAR) thruster system to create a more efficient, higher specific impulse, and lower specific mass system (Ref. 2). The design approach will provide future NASA science missions with the greatest value in mission performance at a low total development cost.

The NEXT thruster is a $36 \mathrm{~cm}$ beam diameter, two-grid ion optics, xenon ion thruster with an input power of 0.5 to $6.9 \mathrm{~kW}$, a maximum specific impulse of over $4100 \mathrm{sec}$, and a maximum thrust greater than $230 \mathrm{mN}$ (Ref. 2). A throttle table containing several of the operating points for the NEXT thruster along with corresponding thrust and specific impulse is given in Table 1 and Table 2. While a limited number of throttle points are indicated in the tables, NEXT is capable of operating at any additional point within the envelope shown. The arrows on the tables indicate typical throttling strategies used on mission analysis that favor either high thrust or high specific impulse use of the engines for the power available. Several potential missions have been evaluated using the NEXT thruster (Ref. 4). These missions included a Saturn mission, Neptune mission, a near Earth asteroid return, comet rendezvous, Vesta-Ceres rendezvous, Titan direct lander, and a comet surface sample return. A $300 \mathrm{~kg}$ xenon throughput requirement, which corresponds to a $1.23 \times 10^{7} \mathrm{~N}$-s total impulse, is derived from these studies with a corresponding $450 \mathrm{~kg}$ qualification level (Ref. 1). Typically these mission studies have followed a high thrust profile similar to that indicated in Table 1. It can be seen that this favors only a portion of the throttle table. This paper will provide a review of the anticipated lifetime of the NEXT thruster components and how the wear changes with throttling.

TABLE 1.-NEXT ION THRUSTER THROTTLE TABLE INCLUDING THRUST AND THRUSTER INPUT POWER [Arrows indicate typical throttling profile followed to maintain maximum thrust for a given input power.]

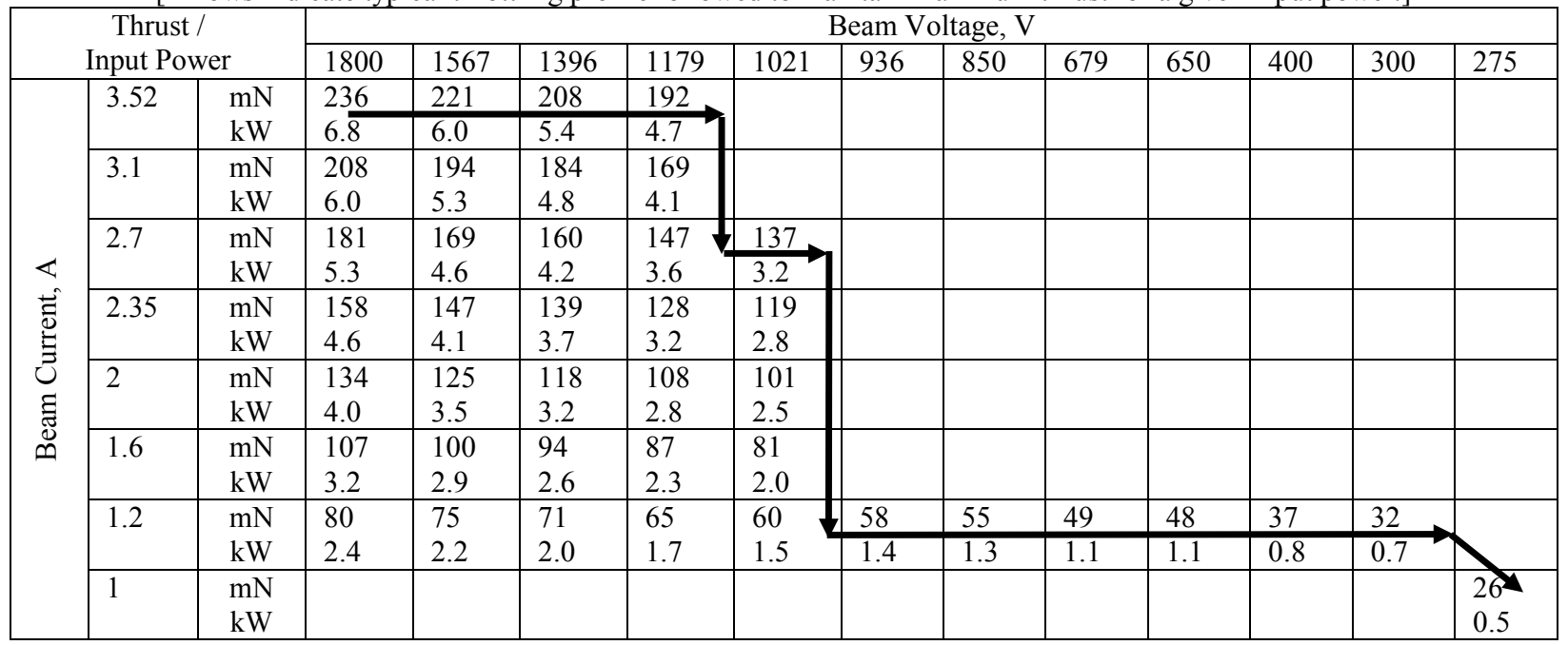


TABLE 2.-NEXT ION THRUSTER THROTTLE TABLE INCLUDING SPECIFIC IMPULSE AND THRUSTER INPUT POWER [Arrows indicate throttling profile followed to maintain maximum specific impulse for a given input power.]

\begin{tabular}{|c|c|c|c|c|c|c|c|c|c|c|c|c|c|c|}
\hline \multirow{2}{*}{\multicolumn{3}{|c|}{$\begin{array}{l}\text { Specific impulse/ } \\
\text { input power }\end{array}$}} & \multicolumn{12}{|c|}{$\begin{array}{c}\text { Beam voltage, } \\
\text { V }\end{array}$} \\
\hline & & & 1800 & 1567 & 1396 & 1179 & 1021 & 936 & 850 & 679 & 650 & 400 & 300 & 275 \\
\hline \multirow{9}{*}{ 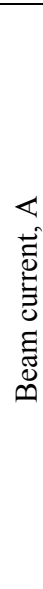 } & 3.52 & $\begin{array}{c}\mathrm{s} \\
\mathrm{kW}\end{array}$ & $\begin{array}{c}4190 \\
6.8\end{array}$ & $\begin{array}{c}3910 \\
6.0\end{array}$ & $\begin{array}{c}3690 \\
5.4\end{array}$ & $\begin{array}{c}3390 \\
4.7\end{array}$ & & & & & & & & \\
\hline & 3.1 & $\begin{array}{c}\mathrm{s} \\
\mathrm{kW}\end{array}$ & $\begin{array}{c}4150 \\
6.0\end{array}$ & $\begin{array}{c}3870 \\
5.3\end{array}$ & $\begin{array}{c}3660 \\
4.8\end{array}$ & $\begin{array}{c}3360 \\
4.1\end{array}$ & & & & & & & & \\
\hline & 2.7 & $\begin{array}{c}\mathrm{s} \\
\mathrm{kW}\end{array}$ & $\begin{array}{c}4150 \\
5.3\end{array}$ & $\begin{array}{c}3870 \\
4.6\end{array}$ & $\begin{array}{c}3660 \\
4.2\end{array}$ & $\begin{array}{c}3360 \\
3.6\end{array}$ & $\begin{array}{c}3130 \\
3.2\end{array}$ & & & & & & & \\
\hline & 2.35 & $\begin{array}{c}\mathrm{s} \\
\mathrm{kW}\end{array}$ & $\begin{array}{c}4100 \\
4.6 \\
\end{array}$ & $\begin{array}{c}3830 \\
4.1 \\
\end{array}$ & $\begin{array}{c}3620 \\
3.7 \\
\end{array}$ & $\begin{array}{c}3320 \\
3.2 \\
\end{array}$ & $\begin{array}{c}3090 \\
2.8 \\
\end{array}$ & & & & & & & \\
\hline & 2 & $\begin{array}{c}\mathrm{s} \\
\mathrm{kW}\end{array}$ & $\begin{array}{c}4310 \\
4.0\end{array}$ & $\begin{array}{c}4020 \\
3.5\end{array}$ & $\begin{array}{c}3800 \\
3.2\end{array}$ & $\begin{array}{c}3490 \\
2.8\end{array}$ & $\begin{array}{c}3250 \\
2.5\end{array}$ & & & & & & & \\
\hline & 1.6 & $\begin{array}{c}\mathrm{s} \\
\mathrm{kW}\end{array}$ & $\begin{array}{c}4190 \\
3.2\end{array}$ & $\begin{array}{c}3910 \\
2.9\end{array}$ & $\begin{array}{c}3690 \\
2.6\end{array}$ & $\begin{array}{c}3390 \\
2.3\end{array}$ & $\begin{array}{c}3160 \\
2.0\end{array}$ & & & & & & & \\
\hline & 1.2 & $\mathrm{~s}$ & 4000 & 3730 & 3530 & 3240 & 3010 & 2880 & 2750 & 2450 & 2400 & 1850 & 1590 & \\
\hline & & $\mathrm{kW}$ & 2.4 & 2.2 & 2.0 & 1.7 & 1.5 & 1.4 & 1.3 & 1.1 & 1.1 & 0.8 & 0.7 & \\
\hline & 1 & $\begin{array}{c}\mathrm{s} \\
\mathrm{kW}\end{array}$ & & & & & & & & & & & & $\begin{array}{c}1400 \\
0.5\end{array}$ \\
\hline
\end{tabular}

Previous extended testing by the NSTAR program examined the wear mechanisms for ion thrusters (Refs. 5, 6, 7, and 8). Several of these wear mechanisms were minimized and mitigated during the NSTAR program, but a set of life-limiting mechanisms was established. Based on these related failure modes, an initial life assessment of the NEXT thruster was prepared during Phase I of the NEXT program (Ref. 9). To date several iterations of life models have been utilized based on the most recent data available for the NEXT thruster. These have included deterministic models for the ion optics (Refs. 10, 11, and 12). and the hollow cathodes (Refs. 9 and 13). Modeling of the thruster was also accomplished using a probabilistic failure analysis (PFA) process described in Reference 14. To date, PFA modeling uncertainties have led to unrealistic results that are not supported by test data. Until these uncertainties are resolved, PFA is of limited value. Further work is continuing to reduce these uncertainties, such as measurement of the grid gap during extended operation (Refs. 15 and 16).

Several tests of the NEXT thruster and its components to evaluate wear mechanisms have already been completed. The NEXT Engineering Model 1 (EM1) thruster was wear-tested for $2038 \mathrm{hr}$ (43 kg of xenon throughput) to evaluate thruster wear (Ref. 17). Two wear mechanisms were revealed that could potentially lead to a premature failure. One was the excessive wear on the discharge cathode keeper orifice plate and the other was excessive wear on the accelerator grid holes beyond a radius of $15.3 \mathrm{~cm}$. While loss of the keeper orifice plate does not result in thruster failure, the keeper electrode does protect the cathode and extend its life. The keeper material was changed to graphite for subsequent designs to achieve significant margin for life. The ion optics design was modified by removing some of the outer holes and making the effective beam diameter $36 \mathrm{~cm}$ instead of the previous $40 \mathrm{~cm}$. The removal of holes was only in regions of low plasma density resulting in effectively similar discharge losses without the added optics wear.

The NEXT Engineering Model 3 (EM3) is currently undergoing a long duration test (LDT) at the NASA Glenn Research Center (Refs. 15 and 16). The intent of this test is to validate and qualify the NEXT propellant throughput capability to a qualification-level of $450 \mathrm{~kg}$. The operation to date has been at a beam power supply voltage of $1800 \mathrm{~V}$ and a beam current of $3.52 \mathrm{~A}$ for the first $13,000 \mathrm{hr}$, then the thruster was throttled to a lower voltage of $1179 \mathrm{~V}$ at the same beam current. EM3 has processed $337 \mathrm{~kg}$ of xenon to date and operated for $16,550 \mathrm{hr}$. As the data from this test continues to become available, it will be incorporated into the life assessment.

Reference 18 provides a detailed NEXT life assessment for critical components including the accelerator grid, but lifetime limits due to electron backstreaming were not fully addressed. The intention of this paper is to examine the accelerator grid aperture hole wall wear that could result in the potentially life limiting reduction of electron backstreaming margin and review other life limiting mechanisms to 
establish appropriate throttling conditions for the LDT. The NEXT lifetime assessment will continue to evolve with time based on the latest test data and modeling and this study provides an update the best understanding of the anticipated life of the thruster. A review of previous ion thruster endurance tests along with the causes of failure is given in Reference 19.

\section{Throttling and Wear Mechanisms}

This paper will not provide detail about the effect of throttling on each potential ion thruster wear mechanism as that can be found in a previously published paper (Ref. 18). The primary failure mechanism over the entire throttle table is predicted to be from accelerator grid groove penetration due to erosion from charge exchange ion possibly resulting in structural failure of the grid. Evaluation of accelerator grid barrel erosion and the related electron backstreaming limit will be expanded in this paper from previous assessments. A review will also be presented for the cathodes and how the mechanisms on each subcomponent vary with throttling, including at what throttle point are the expected to be the most severe.

\section{Accelerator Grid}

As previous mentioned, the primary failure to the thruster over its entire operational envelope defined in the throttle table is expected to be from accelerator grid groove penetration due to erosion from charge exchange ions impinging on the downstream face of the grid, possibly resulting in structural failure. Aside from the three lowest power throttle points operating at or below $780 \mathrm{~W}$ of input power, the harshest pit and groove wear occurs at the peak power throttle point corresponding to $3.52 \mathrm{~A}$ of beam current and $1800 \mathrm{~V}$ of beam voltage. The throughput and lifetime at this throttle point is predicted to be $770 \mathrm{~kg}$ and $36.2 \mathrm{khr}$ respectively (Ref. 18). As can be seen from Figure 1, the lifetime and throughput generally increase as the operating power decrease. The three lowest power throttle points evaluated are predicted to have less propellant throughput than the peak power point, but since they correspond to low beam currents and mass flow rates, the lifetime is expected to exceed the peak power point by $9000 \mathrm{hr}$. The three lowest power throttle points reduced propellant throughputs are due to the larger magnitudes of accelerator grid voltages required for operation. There is likely sufficient electron backstreaming margin such that the accelerator grid voltage can be adjusted and further increase the lifetime of the optics at the lowest three power points (Ref. 20).

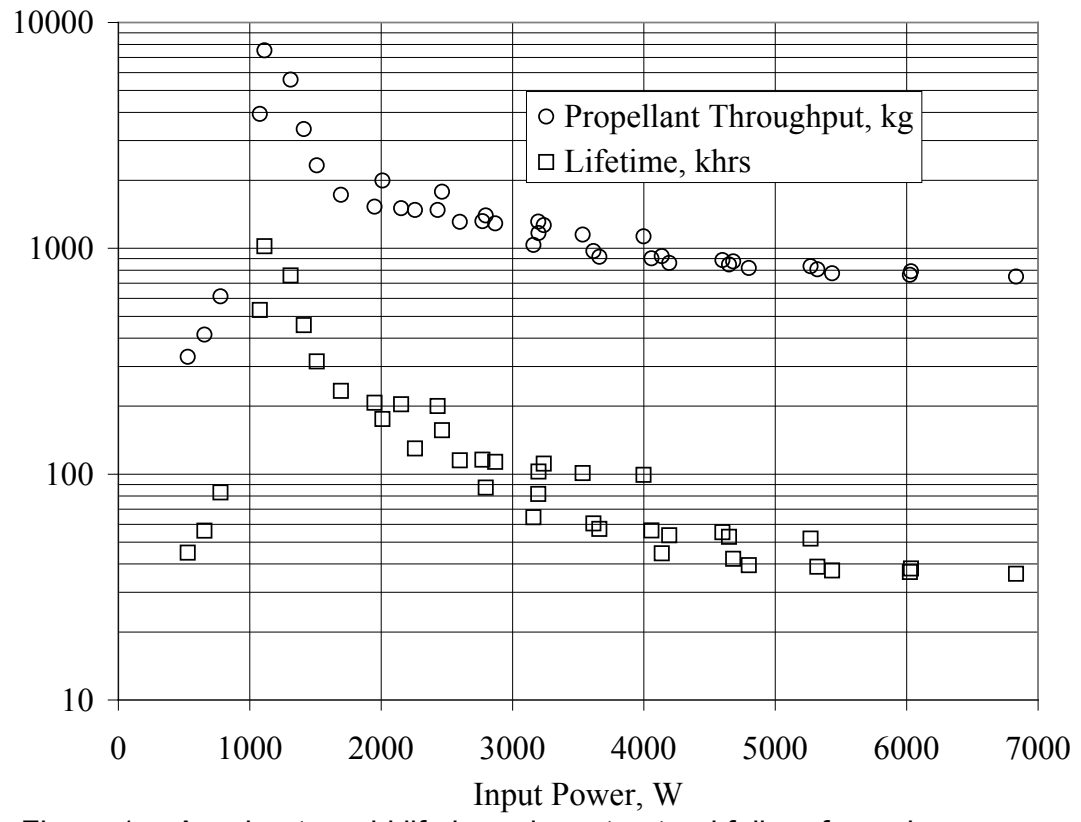

Figure 1.-Accelerator grid life based on structural failure from charge exchange pit and groove erosion (Ref. 18). 
Analysis was performed to assess the NEXT accelerator grid hole wall erosion and corresponding backstreaming limits. This wear mechanism leads to the primary life-limiting failure mode for the Dawn/NSTAR ion thrusters (Ref. 21). Previous modeling of erosion on the accelerator grid barrel from charge exchange ions showed that the normalized hole wall erosion rate per unit area is a strong function of the fraction of maximum perveance (Ref. 22). The fraction of maximum perveance is defined in Reference 22 as the perveance divided by the theoretical maximum perveance for xenon, which is $4.77 \times 10^{-9} \mathrm{~A} / \mathrm{V}^{3 / 2}$. Perveance, $P$, is given as,

$$
P=\frac{j_{b} l_{e}^{2}}{V_{T}^{3 / 2}} ; \quad l_{e}=\sqrt{\left(l_{g}+t_{s}\right)^{2}+\frac{1}{4} d_{S}^{2}}
$$

where $j_{b}$ is the current density between the grids, $l_{e}$ is the effective grid gap, and $V_{T}$ is the total voltage or sum of the beam and accelerator voltage. Figure 2 shows the results from Reference 22 that indicate this correlation. Subsequent modeling has used the same computer code to predict the wear rates for the Dawn/NSTAR ion optics for various throttle points (Ref. 21). However, when modeling the aperture wall erosion of the Dawn/NSTAR ion optics, the normalized wear at the lowest throttle point, TH0, does not support this supposition. The ELT throttle points are given in Table 3. Figure 3 shows the predicted wall erosion rates from that reference versus the fraction of maximum perveance determined using the measured hot grid gaps (Ref. 23). The operation at NSTAR's lowest power throttling point has a lower wear rate predicted than what would be expected based purely on its fraction of maximum perveance. Modeling of the NEXT ion thruster optics using a different computer code also did not support the perveance-hole wall wear rate relationship (Ref. 24).

TABLE 3.-NSTAR ELT THROTTLE CONDITIONS

\begin{tabular}{|c|c|c|c|}
\hline $\begin{array}{c}\text { NSTAR } \\
\text { throttle } \\
\text { number }\end{array}$ & $\begin{array}{c}\text { Beam } \\
\text { current, } \\
\text { A }\end{array}$ & $\begin{array}{c}\text { Beam } \\
\text { voltage, } \\
\text { V }\end{array}$ & $\begin{array}{c}\text { Accelerator } \\
\text { voltage, } \\
\text { V }\end{array}$ \\
\hline TH15 & 1.76 & 1100 & -180 \\
TH12 & 1.49 & 1100 & -180 \\
TH8 & 1.10 & 1100 & -180 \\
TH5 & 0.81 & 1100 & -150 \\
TH0 & 0.51 & 650 & -150 \\
\hline
\end{tabular}

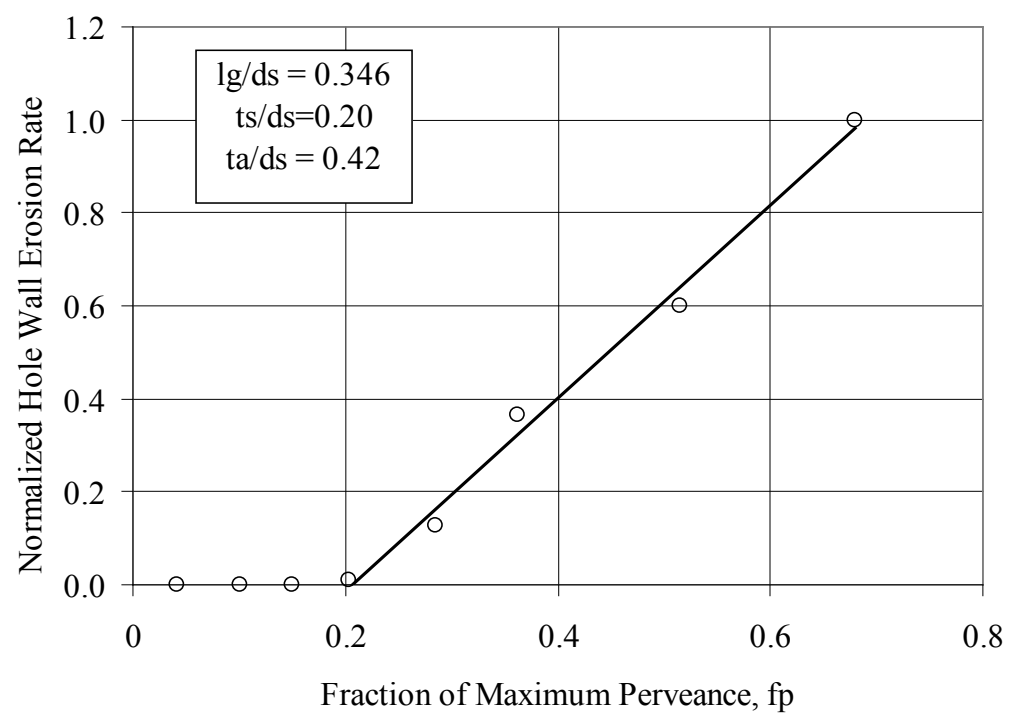

Figure 2.-Normalized hole wall erosion rate as a function of perveance for given generic grid set (Ref. 22). 


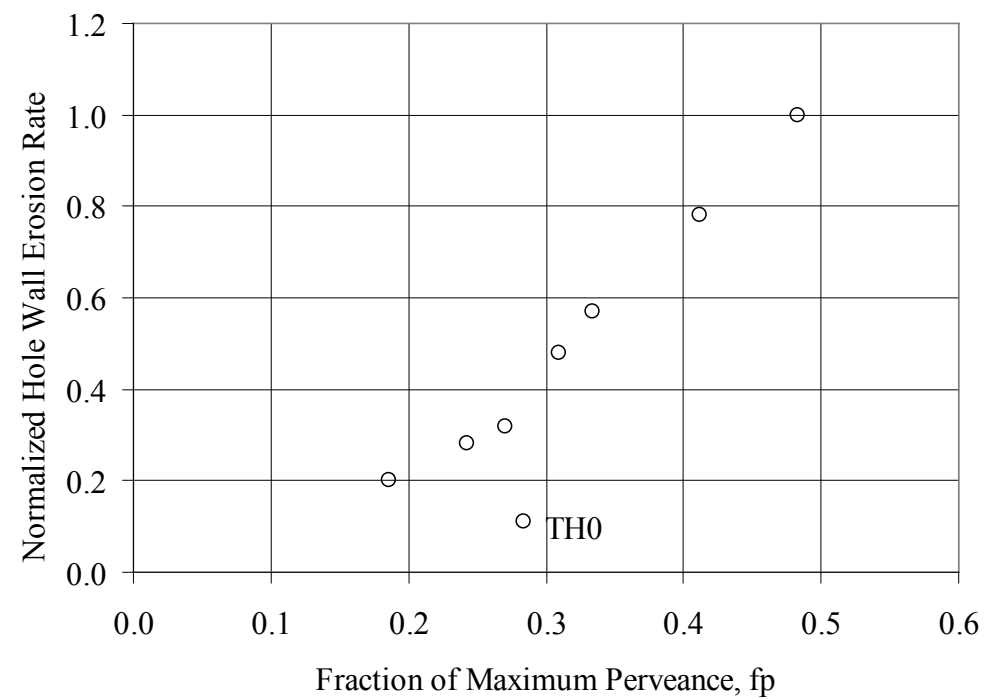

Figure 3.-Normalized hole wall erosion rate for NSTAR/Dawn accelerator grids.

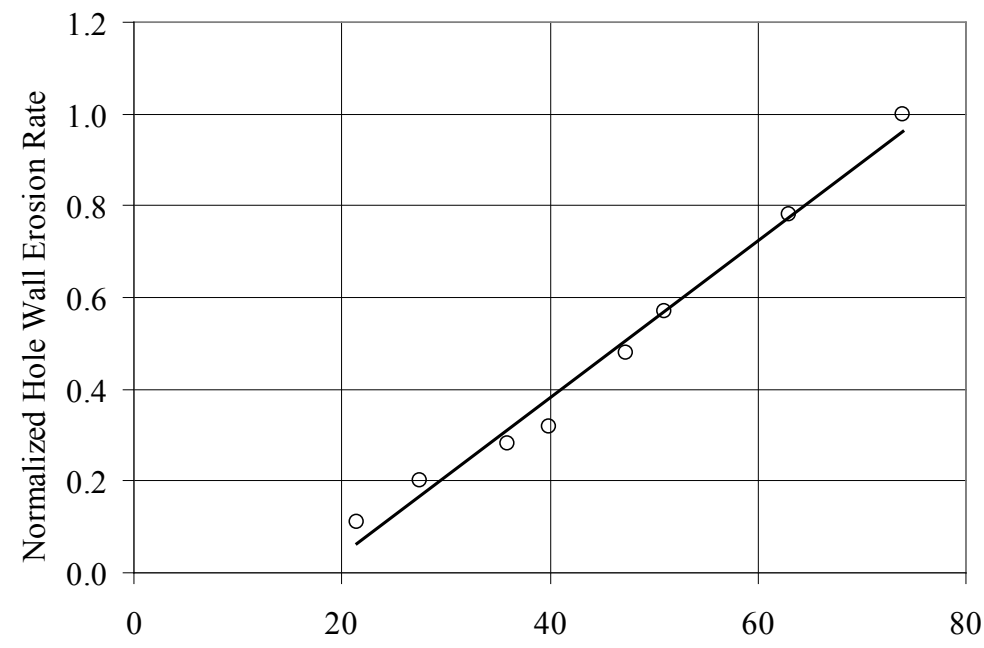

Beamlet Current Density at Beamlet Sheath, $\mathrm{A} / \mathrm{m}^{2}$

Figure 4.-NSTAR/Dawn normalized hole wall erosion rates predicted as a function of beamlet current density.

While it is not explicitly called out in Reference 22, it appears possible that the data to generate Figure 2 was at a fixed total voltage. If this is true, along with a fixed grid gap, it would indicate that the relationship is not defined by perveance, but with the beamlet sheath ion current density. The beamlet sheath current density is calculated in Reference 22 by taking the peak beam current density measured and dividing it by the screen grid ion transparency. The same approach was used in this assessment. For both the NSTAR and NEXT thrusters, the peak beam current densities and screen grid ion transparency are both based on measured data along with interpolations for conditions where measurements were not taken. Figure 4 shows the normalized wear predictions from Reference 21 for the NSTAR/Dawn thruster plotted versus the beamlet current density. The correlation between the beamlet sheath current density and the accelerator aperture wear rate appears strong. While total voltage is expected to have an effect, it appears less pronounced due to counteracting effects experienced in the beamlet plasma. For example, for higher voltages, the beamlet diameter, and hence ion flow volume, generally decreases under the 
conditions at the center aperture, yet the charge-exchange ion energy would likely increase. It should be noted that the exact relationship between the ion density and the wear rate would be expected to change for different ion optics geometries and gaps.

While the NEXT grid geometry $\left(l_{g} / d_{s}=0.21, t_{s} / d_{s}=0.2, t_{a} / d_{s}=0.4\right)$ is slightly different that the NSTAR/Dawn geometry $\left(l_{g} / d_{s}=0.178, t_{s} / d_{s}=0.2, t_{a} / d_{s}=0.267\right)$, it is assumed that the NSTAR erosion data should provide insight into the anticipated hole wall wear of the NEXT optics. The values of $l_{g}$ are hot or operational grid gaps taken from Refs. 15 and 23. Other differences between the two grid sets include the NEXT apertures having much less pronounced cusps and slightly larger accelerator grid aperture diameters at the grid center due to more tightly controlled manufacturing processes(Refs. 25 and 26).

Figure 5 shows the peak beamlet sheath current density over the entire range of the NEXT throttle table. The operating points from the NSTAR Extended Life Test (ELT) are also included for comparison. It can be seen that peak beamlet current density for NSTAR/Dawn thruster corresponding to the worst case hole wall erosion is approximately 50 percent higher than the worst case for the NEXT optics. If the curve established for the NSTAR/Dawn optics (Figure 4) is used, the NEXT optics would experience a 50 percent reduction in the aperture wear rate. By comparison, the worst case barrel erosion for NEXT could be likened to the NSTAR TH8 operating condition.

The beamlet sheath current density can be used to establish the worst case hole wall erosion rate for the NEXT optics. This will occur at a beam current of $3.52 \mathrm{~A}$ and beam voltage of $1179 \mathrm{~V}$. Since there is only a marginal difference in beam current density, this operating point is only expected to produce a wall wear rate at most 5 percent larger than the NEXT full power operating condition. The maximum aperture wear rate and final diameter will have the biggest impact leading to the degradation of electron backstreaming margin.

The beam current density affects not only the rate, but also the final eroded diameter of the accelerator grid hole. Figure 6 shows the minimum aperture diameter of the NSTAR center hole during the ELT. It can be seen that while initially there is a substantial increase in the diameter, this slows down with time and eventually reaches what appears to be a steady state diameter. The diameter approaches between 120 to 125 percent of its starting diameter. The center aperture diameter wear profile with time is representative of a worst-case condition. The apertures which were observed during the ELT all appear to have an achieved a state where the minimum aperture diameter is no longer increasing. It has been previously shown that the mass loss is related to the beam current density (Ref. 27). Figure 7 shows the final aperture diameters measured from the NSTAR ELT normalized to the pretest accelerator center hole diameter. The beam current density measured at the TH15 throttle point is also included on that figure. It can be seen that there is virtually a one-to-one comparison between the final diameter size and the beam current density. The beam current density has not been corrected back to the grid plane and would likely improve the correlation further.

Since the NEXT optics are similar to the NSTAR optics, and the worst case center hole erosion is at a total voltage close to the NSTAR TH15 total voltage, Figure 7 provides a good means to determine the final aperture diameter for the NEXT thruster. The NEXT optics cusps are much less pronounced and the initial starting diameter of the accelerator center grid hole is larger than the NSTAR diameters. Based on Figure 7, the NEXT final accelerator center hole will only have a 2 percent increase from the beginning of life diameter based on a maximum beam current density of $4 \mathrm{~mA} / \mathrm{cm}^{2}$. It is expected that little cusp wear would occur at the highest beamlet sheath current density condition $\left(I_{b}=3.52 \mathrm{~A}, V_{b}=1179 \mathrm{~V}\right)$ or at the peak power operation for NEXT $\left(I_{b}=3.52 \mathrm{~A}, V_{b}=1800 \mathrm{~V}\right)$ since both have similar beak beam current densities. This is supported by the negligible change in the NEXT EM3 thruster accelerator grid center hole minimum diameter after more than $16,000 \mathrm{hr}$ of operation. Since minimal wear is anticipated on the cusp, it is predicted that there will be only a $10 \mathrm{~V}$ reduction on the electron backstreaming margin over the thruster's lifetime. 


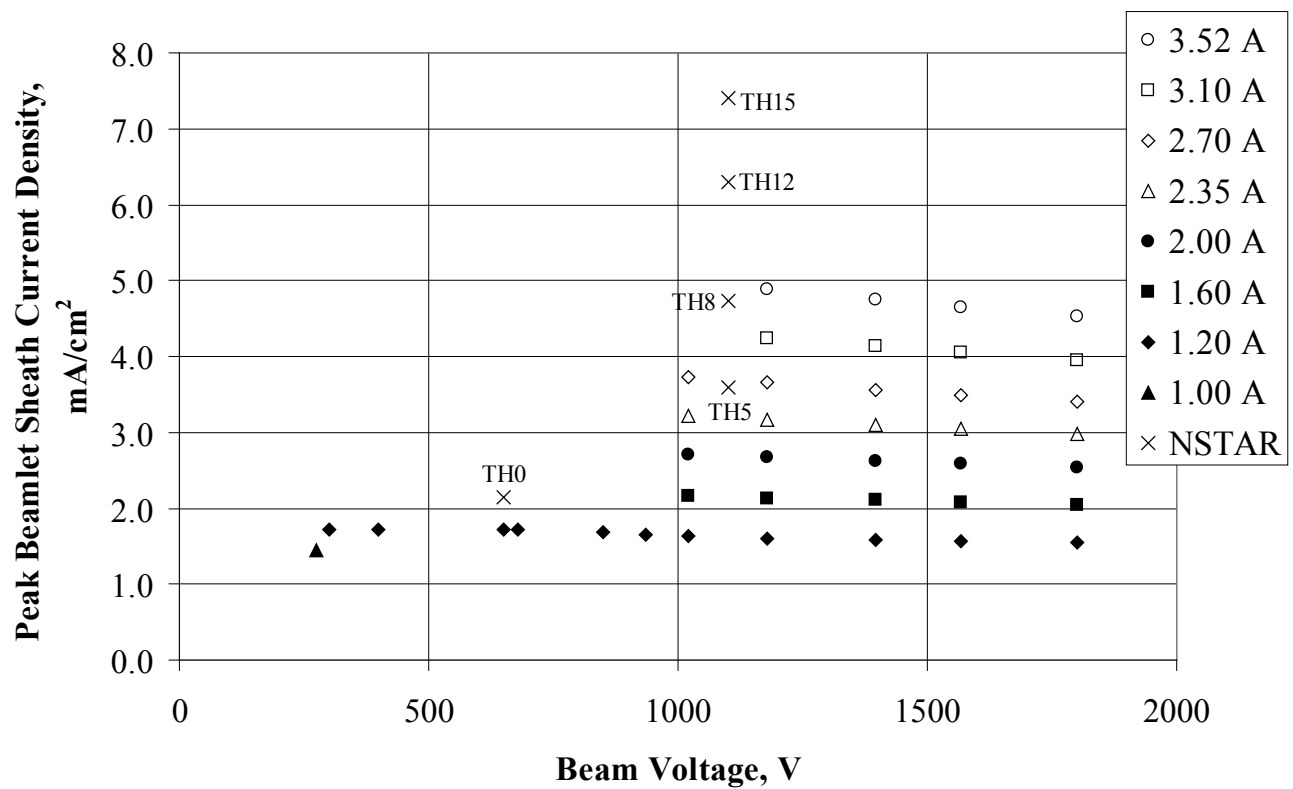

Figure 5.-Peak beamlet sheath current density for NEXT throttle table operating conditions compared to NSTAR ELT operating points.

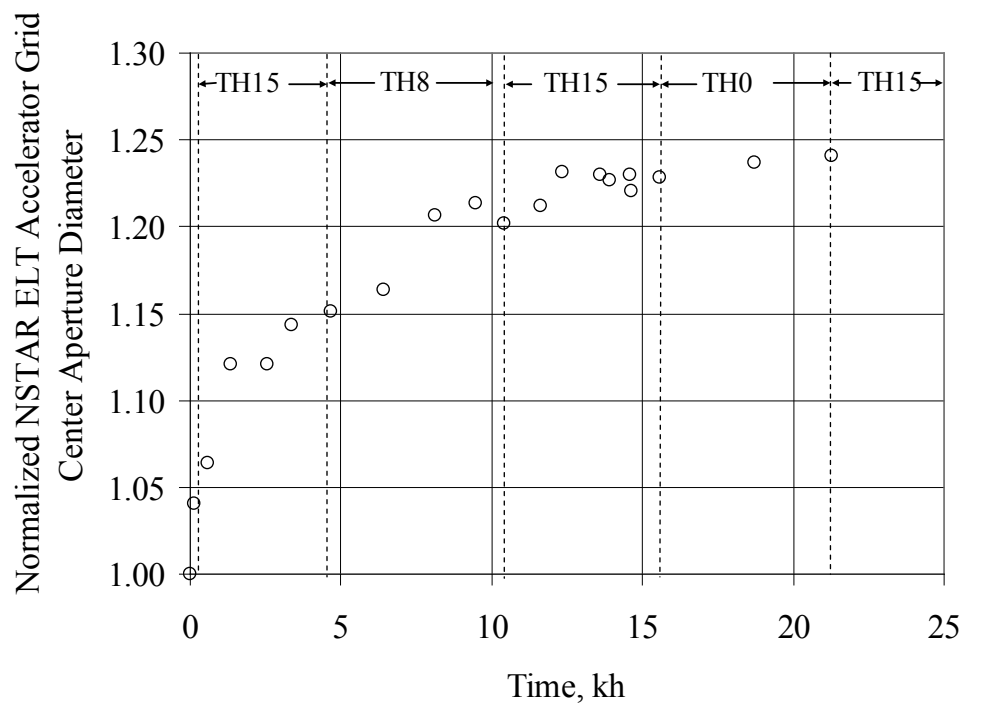

Figure 6.-NSTAR accelerator grid center aperture minimum diameter measured during the ELT. 


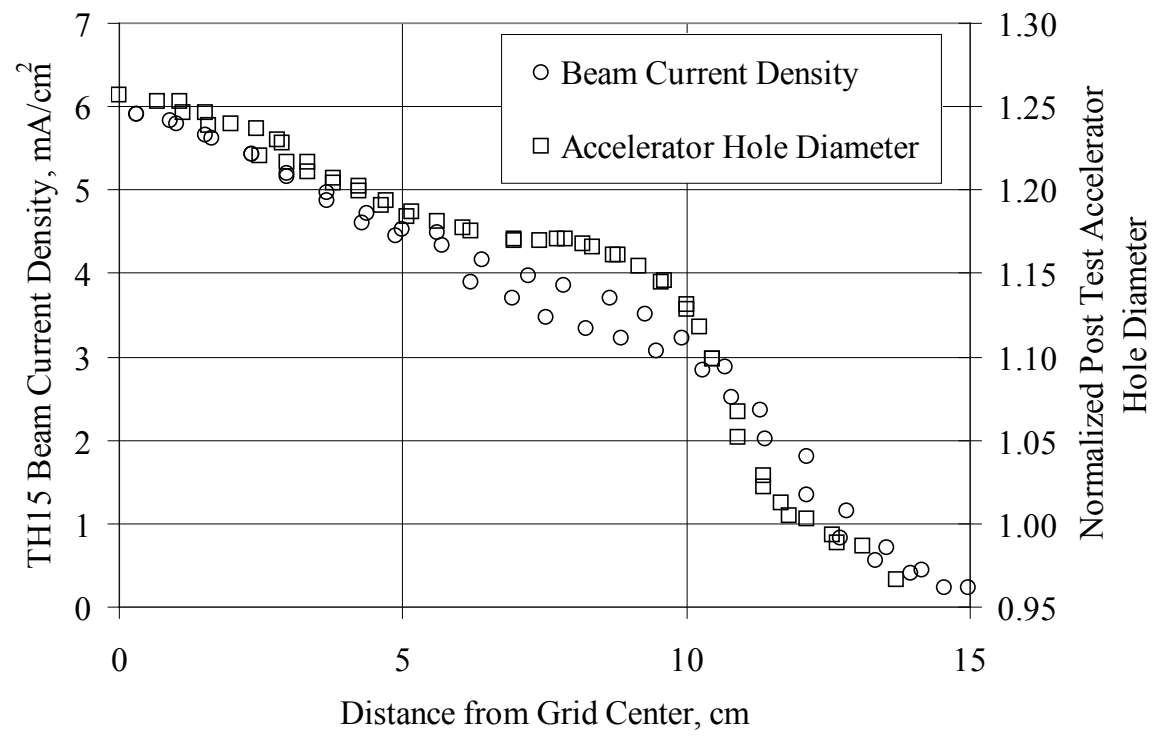

Figure 7.-Comparison of NSTAR TH15 beam current density and normalized post test accelerator hole diameters.

The minimally anticipated center aperture diameter wear is demonstrated in the data from the NEXT LDT. Figure 8 shows the center aperture minimum diameter that has been measured for the current duration of the test. No decrease in cusp diameter was experienced during the peak power condition. In fact, the cusp may have decreased slightly in diameter due to sputtered material being deposited. When operation was changed at $13,000 \mathrm{hr}$ to the maximum beamlet current density $\left(4.7 \mathrm{~kW}, I_{b}=3.52 \mathrm{~A}, V_{b}=\right.$ $1179 \mathrm{~V})$, the diameter increases slightly back to initial diameter. The extent of the wear appears to be only the removal of material that was sputtered onto the aperture. The measured wear data is supported by the measured electron backstreaming margin, as shown in Figure 9. The margin is seen to be extremely steady and to even increase slightly. This slight increase is consistent with the slight decrease in diameter of the accelerator grid hole. The effects of facility backsputtered carbon $(<3.0 \mu \mathrm{m} / \mathrm{khr})$ on accelerator grid life are beyond the scope of this paper.

Reference 21 indicates that the downstream chamfering also appeared to have a noticeable effect on the electron backstreaming limit effect late in the life of the NSTAR/Dawn optics ( $>12,000 \mathrm{hr})$. While the chamfering wasn't measured during the NSTAR ELT, the electron backstreaming limit was measured (Ref. 28). The approach in Reference 21 was to use the final accelerator chamfered dimensions along with the change in backstreaming limit to predict the chamfering during the ELT. After 12,000 hr of operation in the NSTAR ELT, the minimum diameter of the accelerator grid aperture appeared to reach a steady state, yet the backstreaming limit continued to change and appeared most affected by operation at the full power point, TH15. Operation at TH0 and TH5 appeared to have minimal effect on the change in the backstreaming limit and hence the chamfering erosion on the NSTAR optics. Since most of the NEXT operation has beamlet current densities that are appreciably lower than TH15 operation on NSTAR and also that the NEXT accelerator grid is 50 percent thicker, the chamfer wear would be expected to minimally affect the electron backstreaming limit. Chamfering has been seen on the NEXT optics, but this has essentially reached a steady state condition with no consequence on the electron backstreaming margin (Ref. 15). 


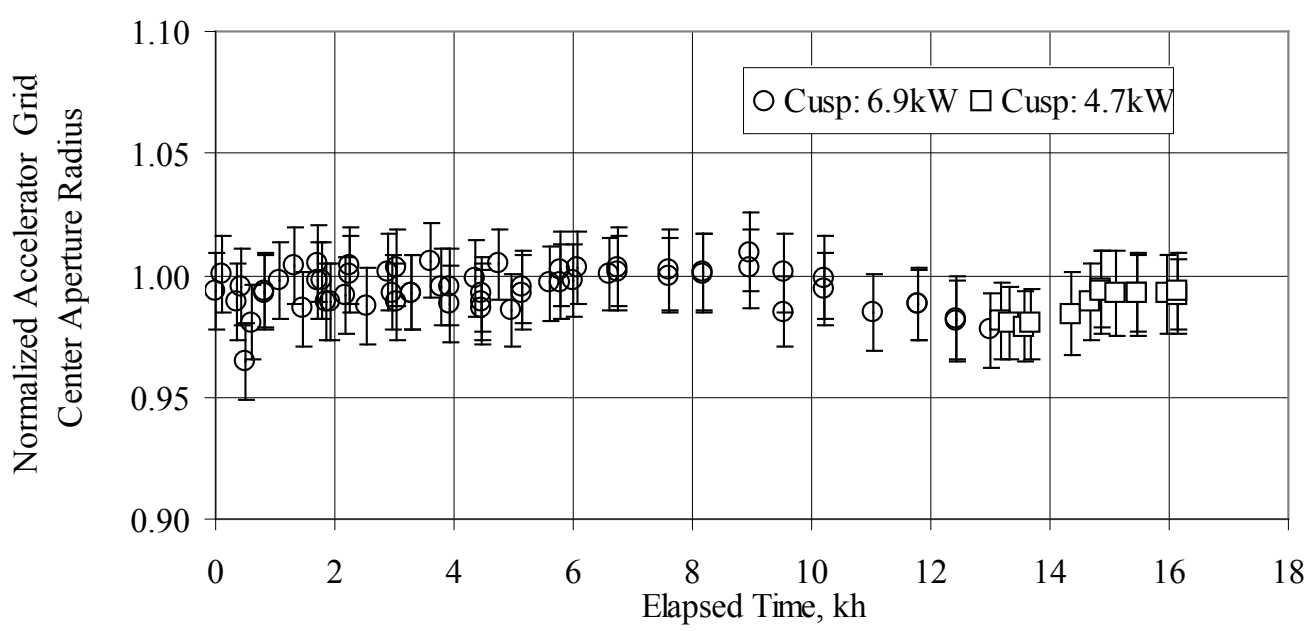

Figure 8.-NEXT thruster center aperture diameters measured during the NEXT LDT.

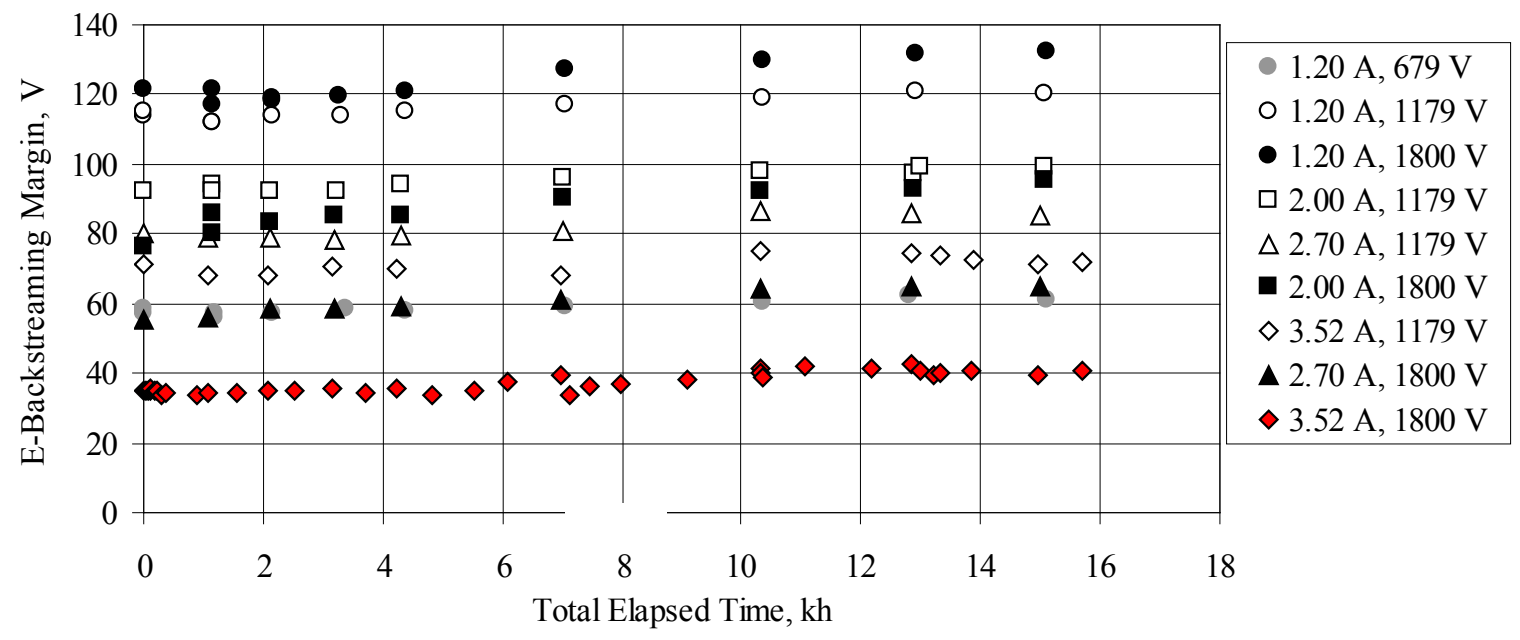

Figure 9.-NEXT thruster electron backstreaming margin as measured in the NEXT LDT.

While aperture wear was significant in the NSTAR thruster, current grid design, manufacturing, and operation in NEXT thruster have significantly reduced its impact. Operation over the current NEXT throttle table is not expected to cause much aperture wear affecting the electron backstreaming margin. This wear mechanism and failure mode has been reduced such that there will be significant life beyond the NEXT thrusters first anticipated failure mode due to groove erosion. The minimal wear experienced in the barrel of the NEXT accelerator grid also allows for an increase in beam current beyond the current throttle table while still maintaining ample life.

The minimum perveance fraction can be used to evaluate the condition at which the highest degree of overfocusing will occur. This operating condition will likely result in the largest amount of grid material sputtered. This will occur in apertures with the lowest beamlet current densities (outer radius apertures) and highest total voltages. For the NEXT thruster, this is at a beam current of $1.2 \mathrm{~A}$ and a beam voltage of $1800 \mathrm{~V}$. While this phenomena is not expected to be a life limiter since the erosion stops once the grid material in the path of the beamlet is removed, it is expected to sputter the highest amount of material and contribute the most to grid recycling. 


\section{NEXT Cathode Lifetimes}

As discussed more thoroughly in Reference 18, there are two major wearout mechanisms related to the discharge cathode. These are insert barium depletion and keeper wear. Figure 10 shows the previously predicted maximum propellant throughputs for electron emitting insert lifetime and Figure 11 shows the previously predicted propellant throughputs for the discharge keeper wear. The depletion of barium from the insert is highly dependent on temperature and hence, the discharge current. While the lifetime due to barium depletion doesn't change much for operation with a beam current of $3.52 \mathrm{~A}$, the minimum lifetime of the insert is at a beam voltage of $1179 \mathrm{~V}$. Operation at this throttle point has higher discharge losses and hence the highest discharge current. The lifetime of this insert is still predicted to be around $1000 \mathrm{~kg}$ of propellant throughput. Operation at $I_{b}=3.52 \mathrm{~A}$ and $V_{b}=1179 \mathrm{~V}$ is also expected to be the severest for the discharge cathode keeper. It is at this condition that ratio between the emission current and the discharge cathode flow rate is that highest and also has the highest discharge voltage. These contribute to the highest keeper wear rates. However, the thruster throughput is still expected to be several thousand kilograms of propellant before the keeper degrades enough to expose the heater.

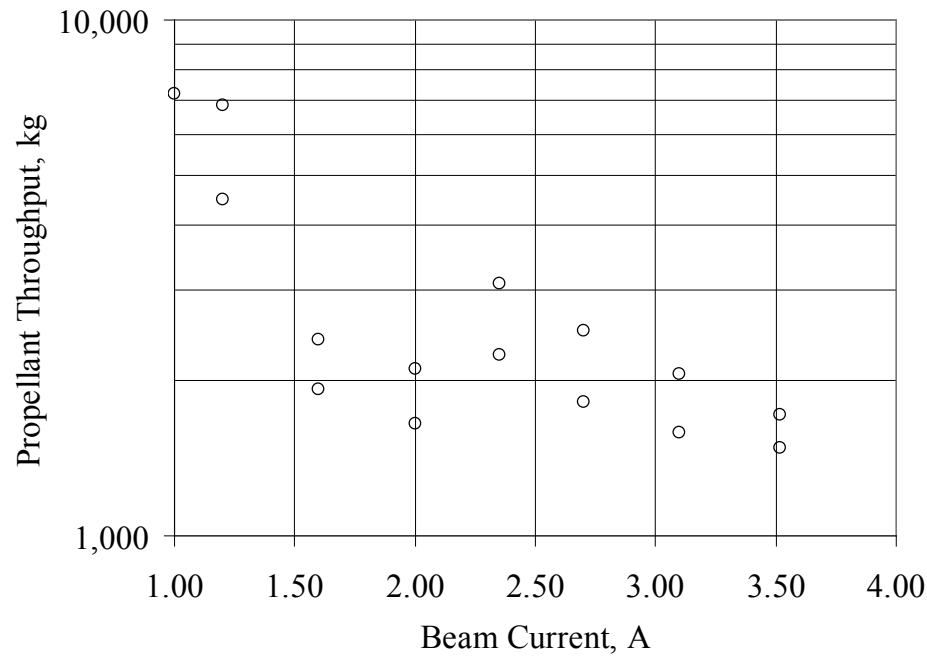

Figure 10.- Insert lifetime of the NEXT discharge cathode (Ref. 18).

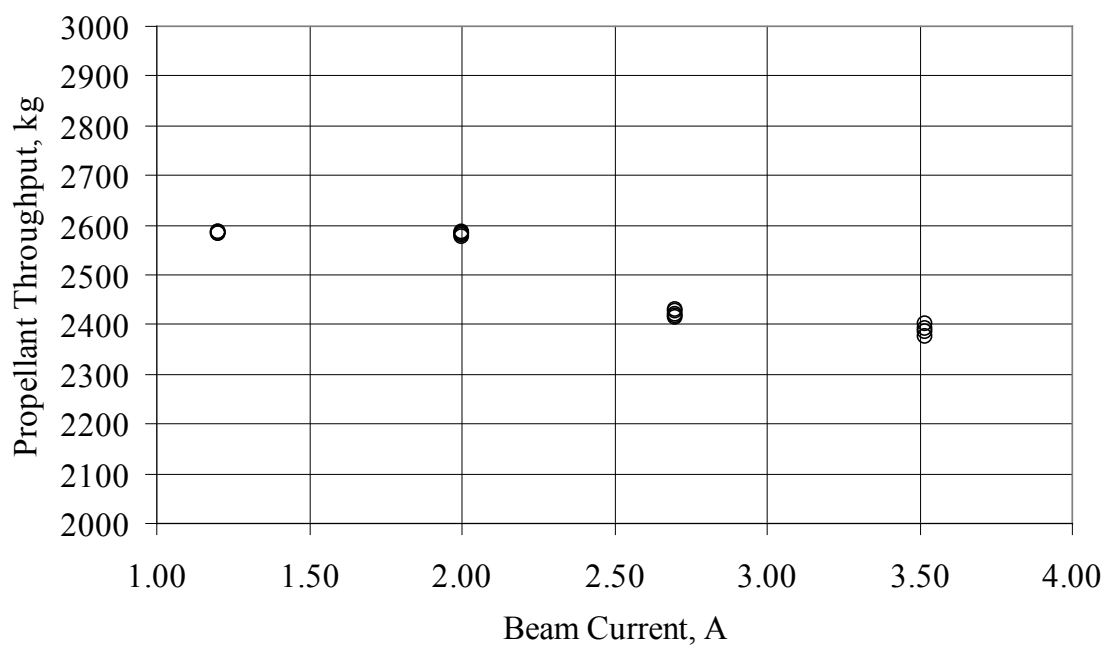

Figure 11.-Lifetime of the NEXT discharge cathode keeper (Ref. 18). 


\section{Determination of LDT Throttling Conditions}

The NEXT long duration test has been synergistic with the lifetime assessment of the NEXT ion thruster. The lifetime assessment has been used to establish what operating points are the most stressful on the life of the thruster and also establish recommended durations to provide sufficient data to demonstrate the wear rates that are present under the harshest conditions. Data is then received from the test and used along with other tests to further develop and validate analytical models. Some of the basic wear related measurements made during the NEXT LDT are grid aperture diameters, accelerator downstream groove erosion, cathode and keeper orifice diameters, and grid gap. Based on the lifetime assessment, four throttle points of interest were established for LDT operation. These throttle points bracketed the throttle table, as can be seen in Table 4, and also had the harshest conditions for corresponding wear mechanism. These throttle points include:

(1) $I_{b}=3.52 \mathrm{~A}, V_{b}=1800 \mathrm{~V}$

(a) Operation at this throttle point establishes wear rates of the first failure mode, namely structural failure of the accelerator grid. The accelerator grid is predicted to have groove penetration from downstream erosion at $36,000 \mathrm{hr}$ of operation at this throttle point corresponding to $750 \mathrm{~kg}$ of propellant throughput (Ref. 18).This is thought to result in structural failure of the grid.

(2) $I_{b}=3.52 \mathrm{~A}, V_{b}=1179 \mathrm{~V}$.

(a) Operation at this throttle point corresponds to the worst case barrel erosion. While accelerator grid hole wall erosion is still anticipated to be minimal and failure due to electron backstreaming is expected to occur well beyond the penetration from groove erosion, operation at this throttle point will help establish the worst case rates. While this throttle point is not expected to have a dramatic effect on the discharge cathode, operation at this throttle point will be the most stressful for the discharge cathode insert and the discharge cathode keeper wear. The first failure mode at this throttle point is still predicted to be due to accelerator grid groove erosion from charge exchange after $42,000 \mathrm{hr}$ and corresponding to $875 \mathrm{~kg}$ of propellant throughput (Ref. 18).

(3) $I_{b}=1.00 \mathrm{~A}, V_{b}=275 \mathrm{~V}$

(a) This throttle point corresponds to the lowest propellant throughput predicted before accelerator grid penetration. This is a result of the greatest negative accelerator voltage required. The propellant throughput predicted is $330 \mathrm{~kg}$ of xenon. However, while the throughput is lowest on the throttle table, it would correspond to $45,000 \mathrm{hr}$ of operation (Ref. 18).

(4) $I_{b}=1.20 \mathrm{~A}, V_{b}=1800 \mathrm{~V}$

(a) While this throttle point will produce the greatest overfocusing of beamlets on the outer apertures, it is not expected to be a life limiter. Operation here will demonstrate operation under the highest optics sputtering conditions. However, once the beamlet has removed the grid material from direct impingement, the wear is anticipated to cease. The first failure mode associated with operation at this throttle point is still predicted to be from groove erosion after $200,000 \mathrm{hr}$ of operation and over $1400 \mathrm{~kg}$ of propellant throughput (Ref. 18). 
TABLE 4.-NEXT THROTTLE TABLE WITH THROTTLE POINTS

CORRESPONDING TO A WORST CASE WEAR MECHANISMS

[Operational throttle points shaded.]

\begin{tabular}{|c|c|c|c|c|c|c|c|c|c|c|c|c|}
\hline \multirow{2}{*}{$\begin{array}{c}\text { Beam } \\
\text { current, } \\
\text { A }\end{array}$} & \multicolumn{12}{|c|}{$\begin{array}{c}\text { Beam voltage, } \\
\text { V }\end{array}$} \\
\hline & 1800 & 1567 & 1396 & 1179 & 1021 & 936 & 850 & 679 & 650 & 400 & 300 & 275 \\
\hline 3.52 & $\begin{array}{l}\text { Highest groove } \\
\text { erosion rate }\end{array}$ & & & $\begin{array}{c}\text { Highest barrel } \\
\text { erosion rate, Shortest } \\
\text { cathode/keeper } \\
\text { lifetime }\end{array}$ & & & & & & & & \\
\hline 3.10 & & & & & & & & & & & & \\
\hline 2.70 & & & & & & & & & & & & \\
\hline 2.35 & & & & & & & & & & & & \\
\hline 2.00 & & & & & & & & & & & & \\
\hline 1.60 & & & & & & & & & & & & \\
\hline 1.20 & $\begin{array}{l}\text { Highest outer } \\
\text { aperture wear }\end{array}$ & & & & $\begin{array}{c}\text { Intermediate } \\
\text { Point }\end{array}$ & & & & & & & \\
\hline 1.00 & & & & & & & & & & & & $\begin{array}{l}\text { Highest groove } \\
\text { erosion based on } \\
\text { throughput }\end{array}$ \\
\hline
\end{tabular}

In addition to the four throttle points that are associated with a wear mechanism, a fifth point is chosen that is intermediate $\left(I_{b}=1.2 \mathrm{~A}, V_{b}=1021 \mathrm{~V}\right)$. This was chosen to provide fairly nominal operation for reference and to ensure there are no unknown and unexpected long-term effects. This throttle point represents a region of the throttle table that was used frequently during mission analysis. It is roughly in the middle of the high thrust profile. The durations chosen at each throttle point were a combination of ensuring sufficient operation to quantify the wear mechanism and also represent typical flight durations. Two to four thousand hours of operation is expected to be the minimum necessary to establish trends from the various throttling conditions. These durations will be adjusted as the test continues to ensure that any wear mechanism is sufficiently quantified.

\section{Conclusion}

An evaluation of thruster wear mechanisms has been presented to determine the best operating conditions for the NEXT Long Duration Test. Several of the wear mechanisms were reviewed from previous work along with a further assessment of the accelerator aperture hole wall erosion and associated electron backstreaming margin. The primary life-limiting mechanism over the entire NEXT thruster operating conditions is still expected to be from pit and groove erosion on the accelerator grid.

Penetration through the accelerator grid is expected to occur after $36,000 \mathrm{hr}$ of operation of the NEXT thruster. While aperture wall wear was significant in the NSTAR thruster, current grid design, manufacturing, and operation in NEXT thruster have significantly reduced its impact. The minimal wear experienced in the barrel of the NEXT accelerator grid also allows for an increase in beam current beyond the current throttle table while still maintaining ample life. To validate the thruster life and aid in verifying its various wear rates, four throttle points of interest were determined. The first throttle point is the peak power throttle point $\left(I_{b}=3.52 \mathrm{~A}, V_{b}=1800 \mathrm{~V}\right)$ to evaluate the harshest wear rates from pit and groove erosion. The second throttle point includes the highest beamlet current density and discharge current $\left(I_{b}=3.52 \mathrm{~A}, V_{b}=1179 \mathrm{~V}\right)$ to evaluate the accelerator hole wall erosion rate, the shortest discharge cathode insert life, and the highest discharge keeper wear. The third throttle point is at the lowest power $\left(I_{b}=1.0 \mathrm{~A}, V_{b}=275 \mathrm{~V}\right)$ to evaluate the highest pit and groove erosion based on propellant throughput. The fourth throttle point $\left(I_{b}=1.2 \mathrm{~A}, V_{b}=1800 \mathrm{~V}\right)$ will have the highest degree of beamlet overfocusing in the outer radius apertures and likely produce the highest degree of sputtered material. These four throttle points effectively span the NEXT operating conditions. Thruster lifetime estimates for these three throttle conditions range from 36,000 to $200,000 \mathrm{hr}$. 


\section{References}

1. Benson, S.W., Patterson, M.J., Vaughan, D.A., Wilson, A.C., and Wong, B.R., "NASA's Evolutionary Thruster (NEXT) Phase 2 Developmental Status," 41st Joint Propulsion Conference and Exhibit, AIAA-2005-4070, Tucson, AZ, Jul. 10-13, 2005.

2. Patterson, M.J. and Benson, S.W., "NEXT Ion Propulsion System Development Status and Performance," 43rd Joint Propulsion Conference and Exhibit, AIAA-2007-5199, Cincinnati, OH, Jul. 8-11, 2007.

3. Mankins, J.C., "Technology Readiness Levels,” White Paper, Apr. 6, 1995, URL: http://www.hq.nasa.gov/office/codeq/trl/trl.pdf [cited Jun. 5, 2007].

4. Oh, D., Benson, S., Witzberger, K., and Cupples, M., "Deep Space Mission Applications for NEXT: NASA's Evolutionary Xenon Thruster," 40th Joint Propulsion Conference and Exhibit, AIAA-20043806, Fort Lauderdale, FL, Jul. 11-14, 2004.

5. Sengupta, A., et al., "An Overview of the Results from the 30,000 Hr Life Test of Deep Space 1 Flight Spare Ion Engine," 40th Joint Propulsion Conference and Exhibit, AIAA-2004-3608, Fort Lauderdale, FL, Jul. 11-14, 2004.

6. Polk, J.E., Anderson, J.R., Brophy, J.R., Rawlin, V.K., Patterson, M.J., Sovey, J., and Hamley, J., "An Overview of the Result from the 8200 Hour Wear Test of the NSTAR Ion Thruster, " 35 th Joint Propulsion Conference and Exhibit, AIAA-1999-2446, Los Angeles, CA, Jun. 20-24, 1999.

7. Patterson, M.J., Rawlin, V.K., Sovey, J.S., Kussmaul, M.J., and Parkes, J., " $2.3 \mathrm{~kW}$ Ion Thruster Wear Test," 31st Joint Propulsion Conference and Exhibit, AIAA-95-2516, San Diego, CA, Jul. 10-12, 1995.

8. Polk, J.E., et al., "A 1000-Hour Wear Test of the NASA NSTAR Ion Thruster, “ 32nd Joint Propulsion Conference and Exhibit, AIAA-1996-2717, Lake Buena Vista, FL, Jul. 1-3, 1996.

9. Patterson, M.J., et al., "NEXT: NASA's Evolutionary Xenon Thruster Development Status," 39th Joint Propulsion Conference and Exhibit, AIAA-2003-4862, Huntsville, AL, Jul. 20-23, 2003.

10. Emhoff, J.W. and Boyd, I.D., "Progress in NEXT Ion Optics Modeling," 40th Joint Propulsion Conference and Exhibit, AIAA-2004-3786, Fort Lauderdale, FL, Jul. 11-14, 2004.

11. Farnell, C.C., Williams, J.D., and Wilbur, P J., "NEXT Ion Optics Simulation Via ffx," 39th Joint Propulsion Conference and Exhibit, AIAA-2003-4869, Huntsville, AL, Jul. 20-23, 2003.

12. Emhoff, J.W. and Boyd, I.D., "Grid Erosion Modeling of the NEXT Ion Thruster Optics," 39th Joint Propulsion Conference and Exhibit, AIAA-2003-4868, Huntsville, AL, Jul. 20-23, 2003.

13. Kovaleski, S.D., "Life Model of Hollow Cathode using a Barium Calcium Aluminate Impregnated Tungsten Emitter," 27th International Electric Propulsion Conference, IEPC-01-276, Pasadena, CA, Oct. 14-19, 2001.

14. Polk, J.E., Moore, N.R., Newlin, L.E., Brophy, J.R., and Ebbeler, D.H., "Probabilistic Analysis of Ion Engine Accelerator Grid Life," 23rd International Electric Propulsion Conference, IEPC-93-176, Seattle, WA, Sep. 13-16, 1993.

15. Herman, D. A., Patterson, M. J., and Soulas, G. S., "NEXT Long-Duration Test Plume and Wear Characteristics after 17,200 h of Operation and $352 \mathrm{~kg}$ of Xenon Processed," 44th ASEE Joint Propulsion Conference \& Exhibit, AIAA-2008-4919, Hartford, CT, Jul. 20-23, 2008.

16. Herman, D.A., Patterson, M.J., and Soulas, G.S., "Performance Characteristics of the NEXT LongDuration Test after 17,200 h of Operation and $352 \mathrm{~kg}$ of Xenon Processed," 44th Joint Propulsion Conference \& Exhibit, AIAA-2008-4527, Hartford, CT, Jul. 20-23, 2008.

17. Soulas, G.C., Kamhawi, H., Patterson, M.J., Britton, M.A., and Frandina, M.M., "NEXT Ion Engine 2000 Hour Wear Test Results," 40th Joint Propulsion Conference and Exhibit, AIAA-2004-3791, Fort Lauderdale, Florida, July 11-14, 2004.

18. Van Noord, J.L., "Lifetime Assessment of the NEXT Ion Thruster," 43rd Joint Propulsion Conference and Exhibit, AIAA-2007-5274, Cincinnati, Ohio, Jul. 8-11, 2007. 
19. Brophy, J.R., Polk, J.E., and Rawlin, V.K., "Ion Engine Service Life Validation by Analysis and Testing," 32nd Joint Propulsion Conference and Exhibit, AIAA-1996-2715, Lake Buena Vista, FL, Jul. 1-3, 1996.

20. Soulas, G.C. and Patterson, M.J, "NEXT Ion Thruster Performance Dispersion Analysis," 43rd Joint Propulsion Conference and Exhibit, AIAA-2007-5213, Cincinnati, OH, Jul. 8-11, 2007.

21. Brophy, J.R., "Propellant Throughput Capability of the Dawn Ion Thrusters," 30th International Electric Propulsion Conference, IEPC-2007-279, Florence, Italy, Sep. 17-20, 2007.

22. Brophy, J.R., Katz, I., Polk, J.E., and Anderson, J.R., "Numerical Simulations of Ion Thruster Accelerator Grid Erosion," 38th Joint Propulsion Conference and Exhibit, AIAA-2002-4261, Indianapolis, IN, Jul. 7-10, 2002.

23. Soulas, G.C. and Frandina, M.M., "Ion Engine Grid Gap Measurement," 40th Joint Propulsion Conference and Exhibit, AIAA-2004-3961, Fort Lauderdale, FL, Jul. 11-14, 2004.

24. Emhoff, J.W., Boyd, I.D., Shepard, S.P., "Numerical Analysis of NEXT Ion Thruster Optics," 28th International Electric Propulsion Conference, IEPC-03-110, Toulouse, France, Mar. 17-21, 2003.

25 Hoskins, W.A., et al., "Development of a Prototype Model ion Thruster for the NEXT System," 40th Joint Propulsion Conference and Exhibit, AIAA-2004-4111, Fort Lauderdale, FL, Jul. 11-14, 2004.

26. Hoskins, W.A., et al., "Overview of the NEXT Ion Propulsion System Program at Aerojet," 41st Joint Propulsion Conference and Exhibit, AIAA-2005-3885, Tucson, AZ, Jul. 10-13, 2005.

27. Polk, J.E., Duchemin, O.B., Ho, C., and Koel, B.E., "The Effect of Carbon Deposition on Accelerator Gird Wear Rates in Ion Engine Ground Testing," 36th Joint Propulsion Conference and Exhibit, AIAA-2000-3662, Huntsville, AL, Jul. 16-19, 2000.

28. Sengupta, A., Brophy, J.R., and Goodfellow, K.D., "Status of the Extended Life Test of the Deep Space 1 Flight Spare Ion Engine After 30,352 Hours of Operation," 39th Joint Propulsion Conference and Exhibit, AIAA-2003-4558, Huntsville, AL, Jul. 20-23, 2003. 


\begin{tabular}{|c|c|c|}
\hline \multicolumn{2}{|c|}{ REPORT DOCUMENTATION PAGE } & $\begin{array}{l}\text { Form Approved } \\
\text { OMB No. 0704-0188 }\end{array}$ \\
\hline \multicolumn{3}{|c|}{$\begin{array}{l}\text { The public reporting burden for this collection of information is estimated to average } 1 \text { hour per response, including the time for reviewing instructions, searching existing data sources, gathering and maintaining the } \\
\text { data needed, and completing and reviewing the collection of information. Send comments regarding this burden estimate or any other aspect of this collection of information, including suggestions for reducing this } \\
\text { burden, to Department of Defense, Washington Headquarters Services, Directorate for Information Operations and Reports (0704-0188), } 21215 \text { Jefferson Davis Highway, Suite } 1224 \text {, Arlington, VA } 22222-24302 \text {. } \\
\text { Respondents should be aware that notwithstanding any other provision of law, no person shall be subject to any penalty for failing to comply with a collection of information if it does not display a currently valid OMB } \\
\text { control number. } \\
\text { PLEASE DO NOT RETURN YOUR FORM TO THE ABOVE ADDRESS. }\end{array}$} \\
\hline $\begin{array}{l}\text { 1. REPORT DATE (DD-MM-YYYY) } \\
01-11-2010\end{array}$ & $\begin{array}{l}\text { 2. REPORT TYPE } \\
\text { Technical Memorandum }\end{array}$ & 3. DATES COVERED (From - To) \\
\hline \multirow{3}{*}{\multicolumn{2}{|c|}{$\begin{array}{l}\text { 4. TITLE AND SUBTITLE } \\
\text { Application of the NEXT Ion Thruster Lifetime Assessment to Thru }\end{array}$}} & 5a. CONTRACT NUMBER \\
\hline & & 5b. GRANT NUMBER \\
\hline & & 5c. PROGRAM ELEMENT NUMBER \\
\hline \multirow{3}{*}{\multicolumn{2}{|c|}{$\begin{array}{l}\text { 6. AUTHOR(S) } \\
\text { Van Noord, Jonathan, L.; Herman, Daniel, A. }\end{array}$}} & 5d. PROJECT NUMBER \\
\hline & & 5e. TASK NUMBER \\
\hline & & $\begin{array}{l}\text { 5f. WORK UNIT NUMBER } \\
\text { WBS } 346620.04 .05 .03 .13\end{array}$ \\
\hline \multicolumn{2}{|c|}{$\begin{array}{l}\text { 7. PERFORMING ORGANIZATION NAME(S) AND ADDRESS(ES) } \\
\text { National Aeronautics and Space Administration } \\
\text { John H. Glenn Research Center at Lewis Field } \\
\text { Cleveland, Ohio 44135-3191 }\end{array}$} & $\begin{array}{l}\text { 8. PERFORMING ORGANIZATION } \\
\text { REPORT NUMBER } \\
\text { E-17496 }\end{array}$ \\
\hline \multirow{2}{*}{\multicolumn{2}{|c|}{$\begin{array}{l}\text { 9. SPONSORING/MONITORING AGENCY NAME(S) AND ADDRESS(ES) } \\
\text { National Aeronautics and Space Administration } \\
\text { Washington, DC 20546-0001 }\end{array}$}} & $\begin{array}{l}\text { 10. SPONSORING/MONITOR'S } \\
\text { ACRONYM(S) } \\
\text { NASA }\end{array}$ \\
\hline & & $\begin{array}{l}\text { 11. SPONSORING/MONITORING } \\
\text { REPORT NUMBER } \\
\text { NASA/TM-2010-216920 }\end{array}$ \\
\hline \multicolumn{3}{|c|}{$\begin{array}{l}\text { 12. DISTRIBUTION/AVAILABILITY STATEMENT } \\
\text { Unclassified-Unlimited } \\
\text { Subject Category: } 20 \\
\text { Available electronically at http://gltrs.grc.nasa.gov } \\
\text { This publication is available from the NASA Center for AeroSpace Information, 443-757-5802 }\end{array}$} \\
\hline
\end{tabular}

\section{SUPPLEMENTARY NOTES}

\section{ABSTRACT}

Ion thrusters are low thrust, high specific impulse devices with typical operational lifetimes of 10,000 to 30,000 hr over a range of throttling conditions. The NEXT ion thruster is the latest generation of ion thrusters under development. The NEXT ion thruster currently has a qualification level propellant throughput requirement of $450 \mathrm{~kg}$ of xenon, which corresponds to roughly 22,000 hr of operation at the highest input power throttling point. This paper will provide a brief review the previous life assessment predictions for various throttling conditions. A further assessment will be presented examining the anticipated accelerator grid hole wall erosion and related electron backstreaming limit. The continued assessment of the NEXT ion thruster indicates that the first failure mode across the throttling range is expected to be in excess of 36,000 hr of operation from charge exchange induced groove erosion. It is at this duration that the groove is predicted to penetrate the accelerator grid possibly resulting in structural failure. Based on these lifetime and mission assessments, a throttling approach is presented for the Long Duration Test to demonstrate NEXT thruster lifetime and validate modeling.

\section{SUBJECT TERMS}

Ion thruster; Ion optics; Hollow cathodes; Electric propulsion; Electrostatic propulsion

\begin{tabular}{|c|c|c|c|c|c|}
\hline \multicolumn{3}{|c|}{ 16. SECURITY CLASSIFICATION OF: } & \multirow{2}{*}{$\begin{array}{l}\text { 17. LIMITATION OF } \\
\text { ABSTRACT } \\
\text { UU }\end{array}$} & \multirow{2}{*}{$\begin{array}{l}\text { 18. NUMBER } \\
\text { OF } \\
\text { PAGES } \\
21\end{array}$} & \multirow{2}{*}{$\begin{array}{l}\text { 19a. NAME OF RESPONSIBLE PERSON } \\
\text { STI Help Desk (email:help@sti.nasa.gov) } \\
\text { 19b. TELEPHONE NUMBER (include area code) } \\
\text { 443-757-5802 }\end{array}$} \\
\hline $\begin{array}{l}\text { a. REPORT } \\
\text { U }\end{array}$ & $\begin{array}{l}\text { b. ABSTRACT } \\
\text { U }\end{array}$ & $\begin{array}{l}\text { c. THIS } \\
\text { PAGE } \\
\text { U }\end{array}$ & & & \\
\hline
\end{tabular}



